prof. dr hab. inz. Marian Medwid

dr inz. Rafat Cichy

mgr inż. Marcin Kruś

mgr inż. Jarostaw Czerwiński

Instytut Pojazdów Szynowych ,TABOR”

\title{
Symulacyjne badania numeryczne wytrzymłości konstrukcji adapterów taboru bimodalnego do ruchu ,S” i ,SS"
}

\begin{abstract}
$W$ artykule przedstawiono wybrane wyniki badań symulacyjnych wytrzymatości konstrukcji adapterów i elementów połaczenia adapter - naczepa. Projekt konstrukcyjny opracowano w ramach realizacji badawczego projektu rozwojowego $n r R 1003503$ dotyczacego wykonania prototypu taboru bimodalnego przeznaczonego do ruchu „, ${ }^{\prime}$ i „SS".
\end{abstract}

\section{Wstęp}

Transport kombinowany kolejowo - drogowy jest portu, kolejowy i drogowy. Towarowy transport drogowy charakteryzuje się dużą mobilnością, łatwym przewozy od „drzwi do drzwi”. Cechy negatywne towarowego transportu drogowego to intensywna degradacja dróg kołowych, degradacja środowiska (duża emisja $\mathrm{CO} 2$, drgania i hałas), wypadki drogowe oraz inne czynniki tworzące tzw. koszty zewnętrzne transportu.

Transport kolejowy jest transportem ekologicznym i energooszczędnym generującym ponad czterokrotnie mniejsze koszty zewnętrzne.

Jednym z systemów transportowych pozwalających realizować przewozy towarowe w ruchu kombinowanym, kolejowo - drogowym jest system bimodalny, który łączy pozytywne cechy transportu drogowego i kolejowego. dziedziną transportu, która łączy dwie gałęzie transdostępem do infrastruktury, drogowej i realizuje

W Instytucie Pojazdów Szynowych „TABOR” w Poznaniu w latach 1993 - 1995 opracowano dokumentację techniczną oraz prototyp taboru bimodalnego przystosowanego do jazdy z prędkością maksymalną $160 \mathrm{~km} / \mathrm{h}$.

Układy biegowe wagonów towarowych są w zdecydowanej większości przystosowane do ruchu „S” i „SS” to jest do prędkości $100 \mathrm{~km} / \mathrm{h}$ przy nacisku osi na tor $225 \mathrm{KN}$ oraz $120 \mathrm{~km} / \mathrm{h}$ przy nacisku osi zestawu kołowego $200 \mathrm{KN}$.

W 2011 roku wykonano prototyp taboru bimodalnego przystosowany do ruchu „S” i „SS” na bazie standardowych wózków Y25 [1]. W zbudowanym prototypie zastosowano zmodernizowane adaptery. $\mathrm{W}$ adapterze środkowym wprowadzono połączenie adaptera dolnego z górnym za pośrednictwem typowego przegubu kulistego a $\mathrm{w}$ adapterze końcowym zmieniono profile i układ elementów nośnych ramy adaptera, w odniesieniu do adapterów opracowanych dla taboru przeznaczonego do prędkości ruchu

a)
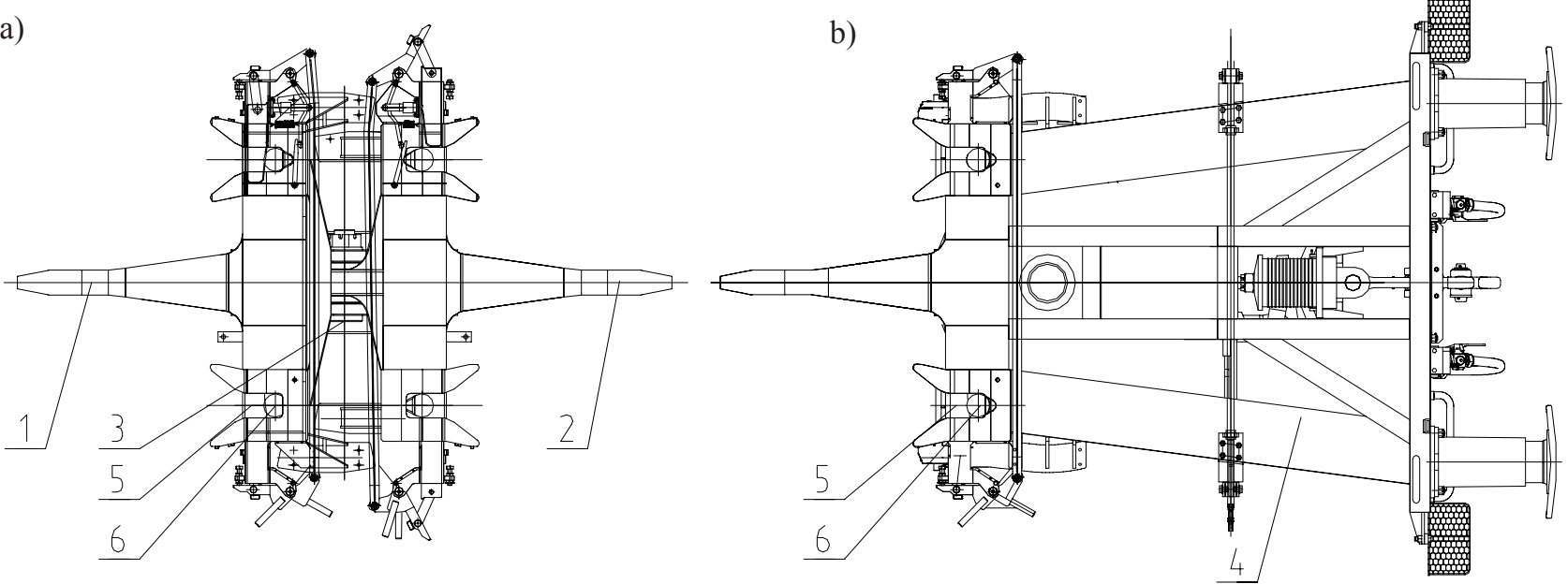
c)

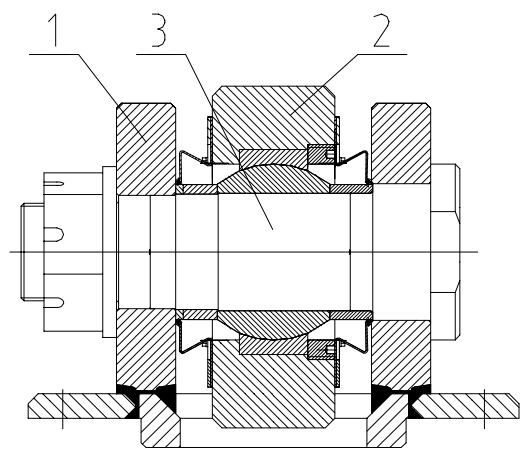

d)

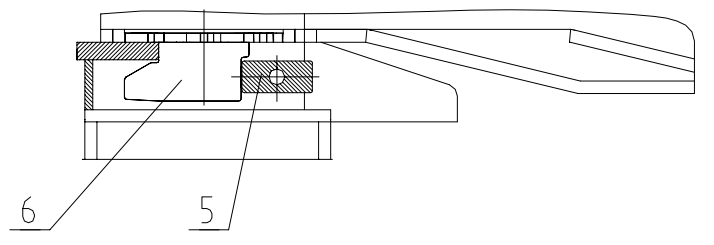

Rys. 1. Elementy konstrukcyjne systemu: a) adapter środkowy, b)adapter końcowy, c) szczegół połączenia między adapterami górnym i dolnym, d) szczegół połączenia naczepy $\mathrm{z}$ adapterem - adapter dolny 1, - adapter górny 2, - sworzeń połączenia adapterów 3, - adapter końcowy 4,- klin ryglujący 5 , - czop sprzęgowy naczepy 6.

$160 \mathrm{~km} / \mathrm{h}$.

Zmodernizowana konstrukcja adapterów powstała w oparciu o szczegółową analizę numeryczną wytrzymałości konstrukcji adapterów ze szczególnym uwzględnieniem ograniczenia masy własnej. Wybrane przykłady wyników przeprowadzonych analiz przedstawiono w dalszej części opracowania.

\section{Obiekt badań}

Obiektem badań symulacyjnych jest konstrukcja adaptera środkowego i końcowego oraz elementy połączenia adapter - naczepa przedstawione na rysunku 1, gdzie odpowiednio oznaczono: a, b, c, d.

Badania symulacyjne przeprowadzono dla obciążeń określonych w przepisach UIC 597 [2] oraz UIC 577 [3] i wytyczne konstruktora prowadzącego, które określają podstawowe wielkości sił jakie należało uwzględnić w badaniach. Siły zewnętrzne obciążające konstrukcje adapterów są wynikiem oddziaływania ciężaru naczepy zamocowanej na adapterach, obciążenie pionowe oraz oddziaływaniem występującym pomiędzy sąsiednimi naczepami $\mathrm{w}$ ruchu pociągu, obciążenia wzdłużne.

\section{Zakres i metodyka badań oraz kryteria oceny}

Zgodnie z wymaganiami [2] zespoły nośne składu bimodalnego winny zapewnić wytrzymałość konstrukcji w zakresie obciążeń:
- obciążenia eksploatacyjne, ściskanie i rozciaganie pociagu w stanie próżnym i ładownym siłą $\pm 850 \mathrm{kN}$,

- przepisy [2]obligują również do wykonania badań wytrzymałości konstrukcji pod obciążeniem nadzwyczajnym rozciaganie składu pociagu $\mathrm{w}$ stanie próżnym siłą $1700 \mathrm{kN}$.

Symulacyjne badania wytrzymałości rozszerzono poza obszar wymagań stawianych w [2] i przeprowadzono analizę wytrzymałości również dla następujących stanów obciążeń:

- ściskanie składu pociągu w stanie próżnym i ładownym siłą $1200 \mathrm{kN}$,

Konstrukcja adapterów i elementów połączenia między adapterami wymaga zastosowania różnych materiałów. Adaptery wykonano ze stali niskostopowej S460N (18G2V) o podwyższonej wytrzymałości. Sworzeń łączący adapter dolny z górnym, klin ryglujący i czop naczepy ze stali stopowej do ulepszania cieplnego 42CrMo4 (40HM). Podstawowe charakterystyki tych materiałów przedstawiono w tabeli 1.

Do badań symulacyjnych utworzono modele obliczeniowe poszczególnych zespołów i elementów, które pokazano na rysunkach
Charakterystyki materiałów adaptera i elementów połączeniowych

Tabela 1

\begin{tabular}{|c|c|c|c|c|}
\hline Element & Typ stali & $\begin{array}{c}\text { Grubość elementu } \\
{[\mathrm{mm}]}\end{array}$ & $\begin{array}{c}\text { Granica plastyczności } \\
\text { Re [MPa] }\end{array}$ & $\begin{array}{c}\text { Wytrzymałość doraź- } \\
\text { na Rm [MPa] }\end{array}$ \\
\hline adapter & $\begin{array}{c}\text { S460N } \\
(18 \mathrm{G} 2 \mathrm{~V})\end{array}$ & $16-30$ & 460 & $580-740$ \\
\hline $\begin{array}{c}\text { klin ryglujący, swo- } \\
\text { rzeń, czop naczepy }\end{array}$ & $\begin{array}{c}42 \mathrm{CrMo} 4 \\
(40 \mathrm{HM})\end{array}$ & $40-160$ & 880 & 1030 \\
\hline
\end{tabular}

Wartości naprężeń dopuszczalnych dla adapterów

Tabela 2

\begin{tabular}{|c|c|c|c|}
\hline Gatunek stali & Grubość $[\mathrm{mm}]$ & \multicolumn{2}{|c|}{ Naprężenia dopuszczalne $\delta_{\text {dop }}[\mathrm{MPa}]$} \\
\hline E460JR & \multirow{2}{*}{$16-30$} & Obszar spoin czołowych & Materiał rodzimy \\
\cline { 3 - 4 } & $(18 \mathrm{G} 2 \mathrm{AV})$ & 409 & 450 \\
\hline
\end{tabular}


Modele podzielono na odpowiednie elementy skończone oraz obciążono siłami czynnymi i reakcjami wynikającymi z warunków równowagi.

Badania modeli przeprowadzono metodą numeryczną korzystając z programu obliczeniowego COSMOS $[4,5,6,7]$. Analizie wytrzymałościowej podlegają wartości naprężeń zredukowanych $\delta_{\text {red }} \mathrm{W}$ poszczególnych miejscach konstrukcji, które są wyznaczone zgodnie z hipotezą wytężeniową energii odkształcenia postaciowego Hubera - Misesa. Wartości naprężeń nie mogą $\mathrm{w}$ zadanym punkcie przekroczyć wartości dopuszczalnych $\delta_{\text {dop }}$ określonych dla danego gatunku materiałów.

Dla konstrukcji spawanej adapterów wartości naprężeń dopuszczalnych podano w tabeli 2.

Dla badań wytrzymałości konstrukcji pod obciążeniem eksploatacyjnym za kryterium oceny przyjęto graniczny poziom naprężeń o wartości:

$$
\delta_{\text {red }}=\delta_{\text {dop }}<\operatorname{Re}
$$

Dla obciążeń nadzwyczajnych obowiązuje kryterium nieprzekroczenia granicznej wytrzymałości doraźnej Rm. W tym przypadku obciążona konstrukcja może ulec niewielkim odkształceniom trwałym, przy czym nie może dojść do rozerwania konstrukcji zwłaszcza przy próbie rozciagania siłą $1700 \mathrm{kN}$.

\section{Wyniki badań}

Zakres przeprowadzonych badań symulacyjnych obejmował obciążenie konstrukcji zespołów nośnych taboru maksymalnymi siłami spotykanymi podczas eksploatacji oraz obciążeniem nadzwyczajnym przyłożonym do konstrukcji podczas statycznych stanowiskowych badań wytrzymałościowych. Ze względu na obszerny zakres analizowanych przypadków obciążeń uwzględnionych $\mathrm{w}$ przeprowadzonych badaniach symulacyjnych $w$ niniejszym opracowaniu przedstawiono wyniki badań dla obciążeń nadzwyczajnych.

Modele obliczeniowe zespołów i elementów konstrukcji nośnych oraz rozkład naprężeń zredukowanych pokazano na rysunkach $2 \div 24$.

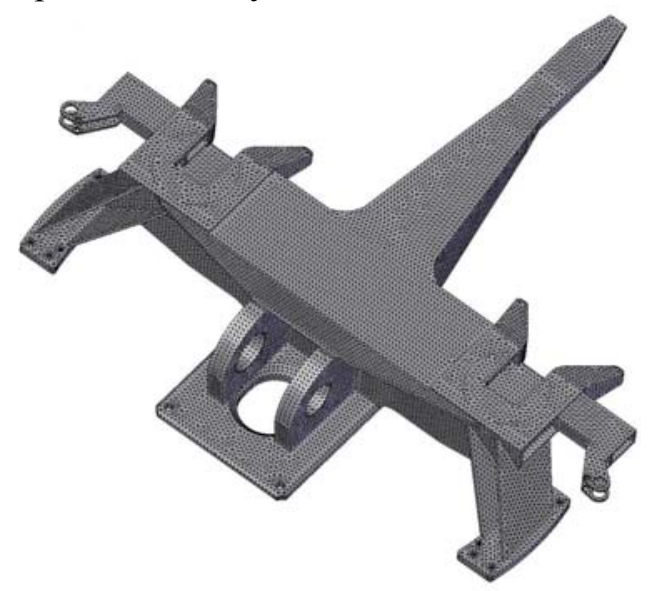

Rys. 2. Podział modelu obliczeniowego adaptera dolnego na elementy skończone a)

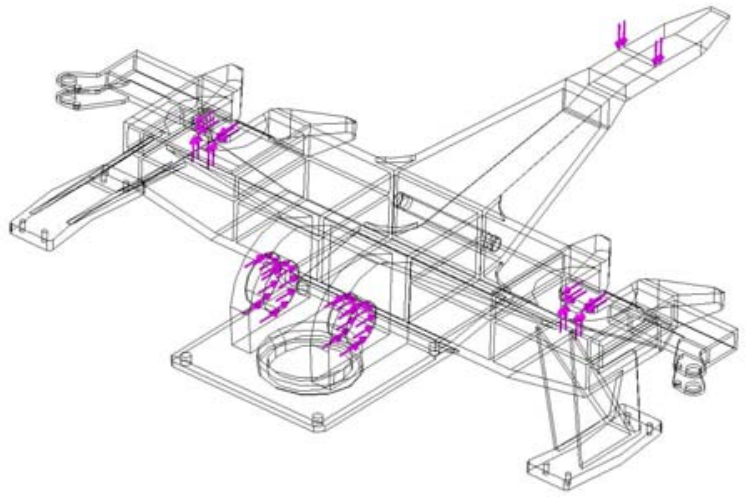

b)

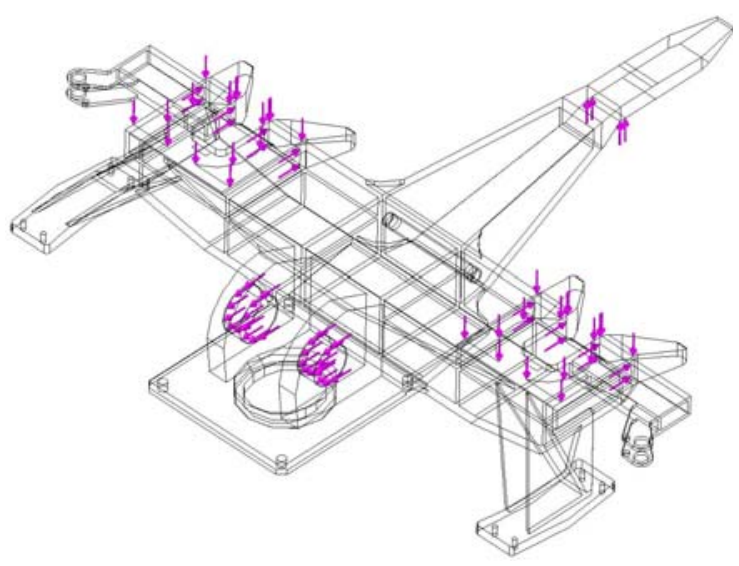

Rys. 3. Sposób przyłożenia sił do modelu: a) obciążenie wzdłużne ściskające b) obciążenie wzdłużne rozciagające

a)

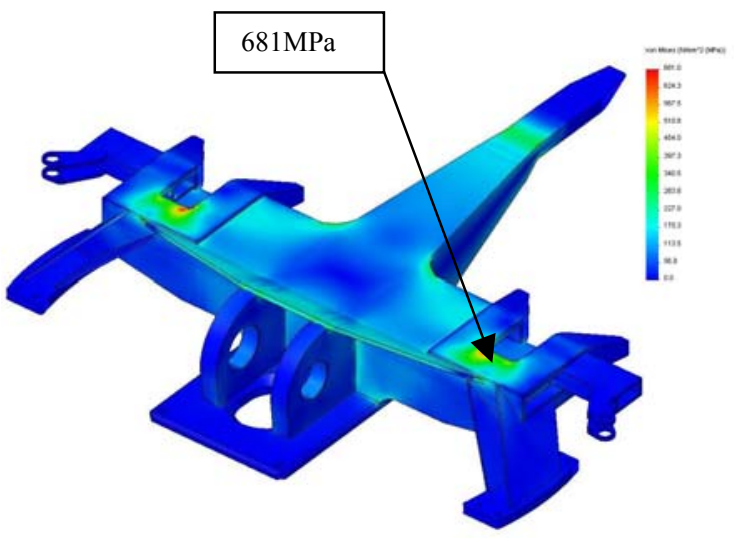

b)

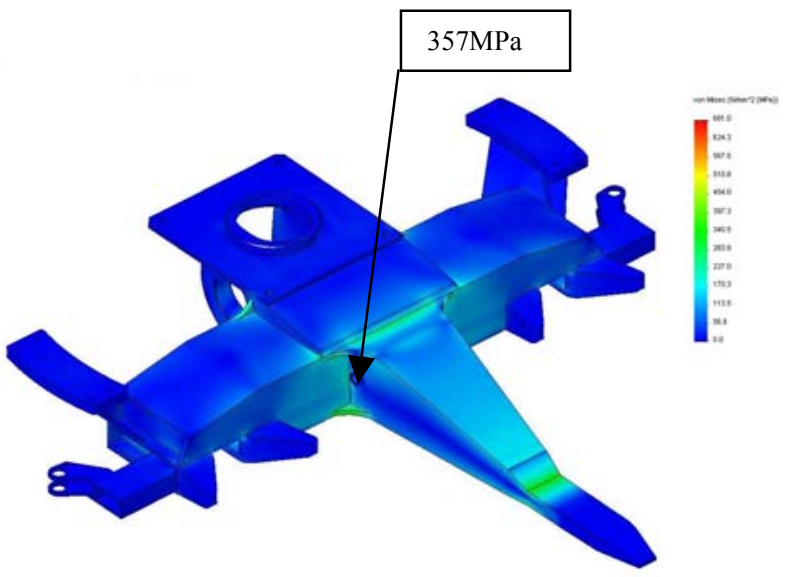

Rys. 4. Rozkład naprężeń zredukowanych w adapterze dolnym przy ściskaniu siłą $1200 \mathrm{kN}$

a) widok $z$ góry, b) widok $z$ dołu 
a)

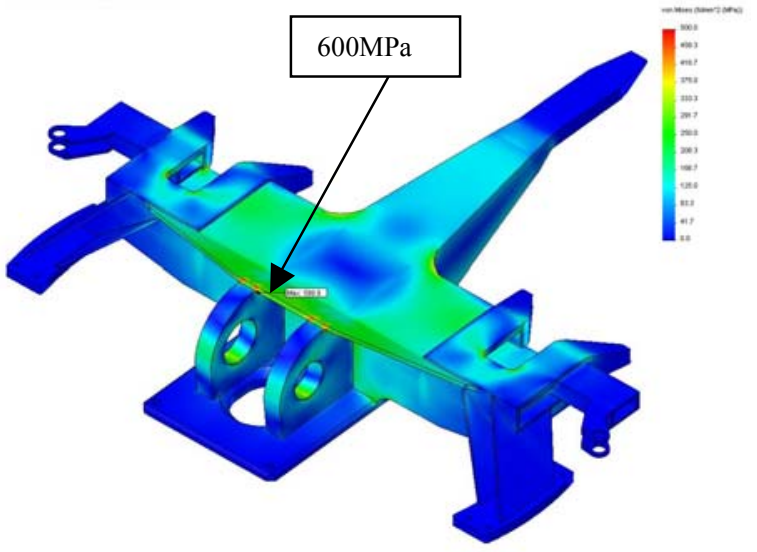

b)

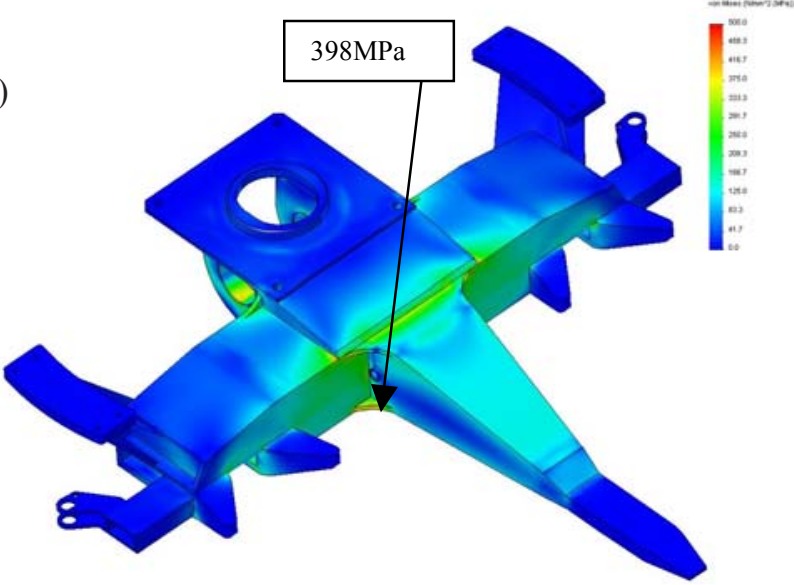

Rys. 5. Rozkład naprężeń zredukowanych w adapterze dolnym przy rozciaganiu siłą $1700 \mathrm{kN}$

a) widok $z$ góry, b) widok $z$ dołu

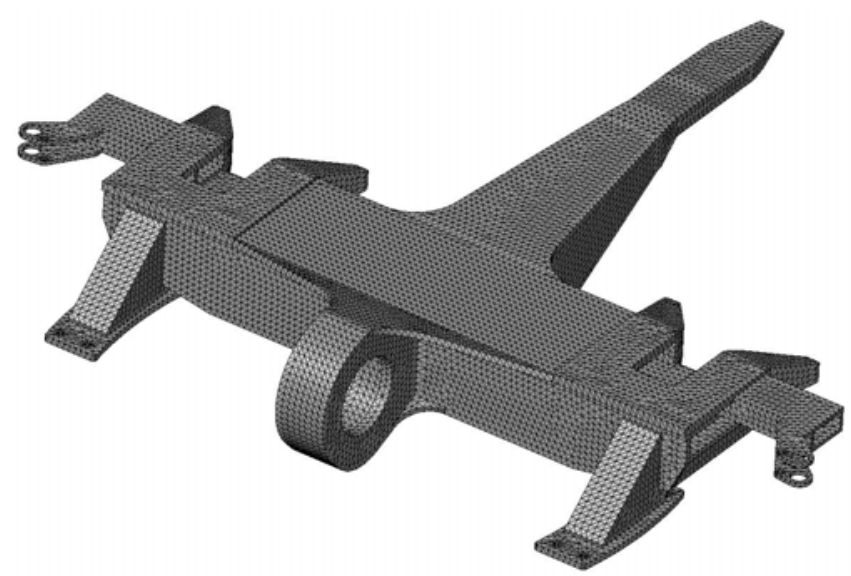

Rys. 6. Podział modelu obliczeniowego adaptera górnego na elementy skończone

a)

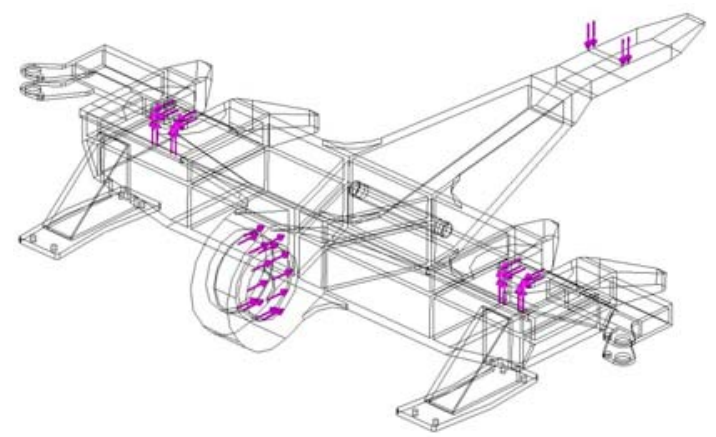

b)

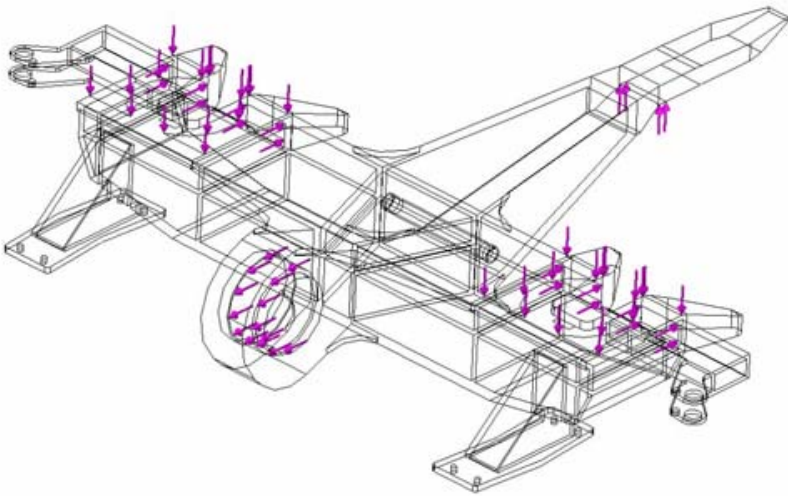

Rys. 7. Sposób przyłożenia sił do modelu: a) obciążenie wzdłużne ściskające b) obciążenie wzdłużne rozciaggające

a)

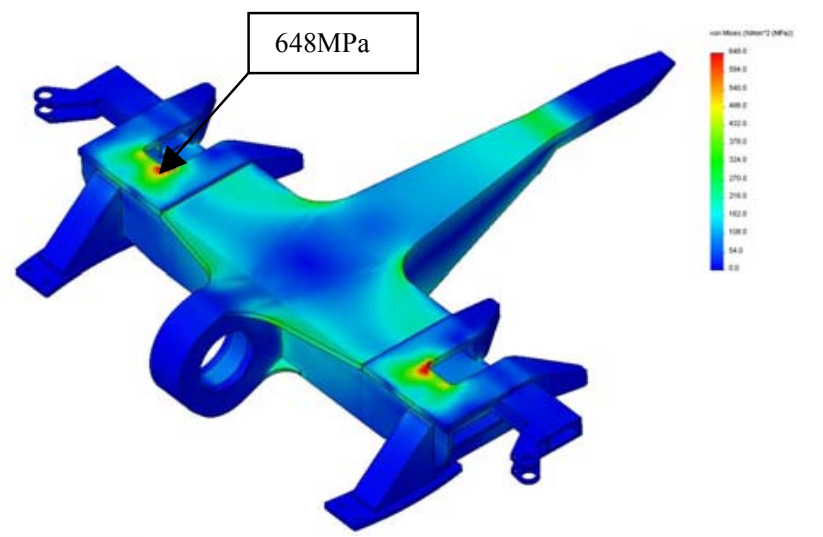

b)



Rys. 8. Rozkład naprężeń zredukowanych w adapterze górnym powstający przy ściskaniu siłą $1200 \mathrm{kN}$ : a) widok z góry, b) widok z dołu

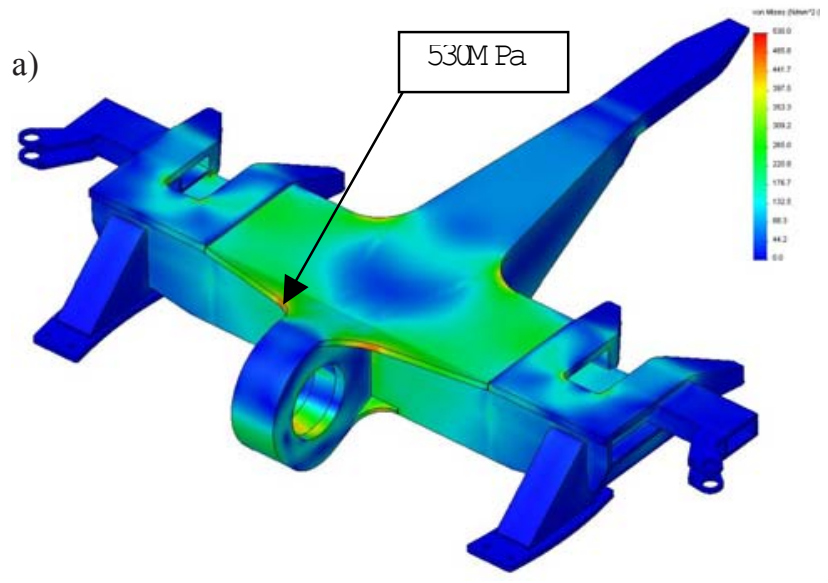




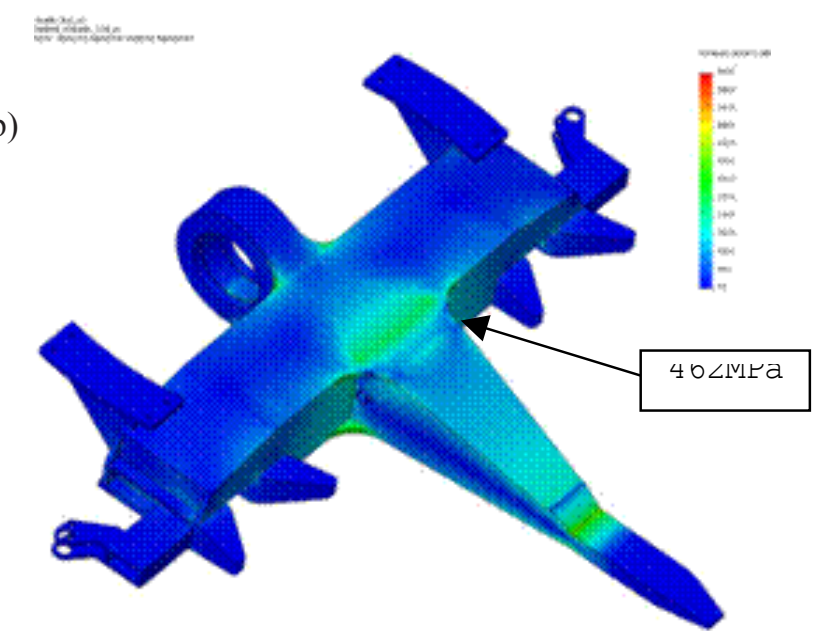

Rys. 9. Rozkład naprężeń zredukowanych w adapterze górnym przy rozciąganiu siłą $1700 \mathrm{kN}$

a) widok z góry, b) widok $z$ dołu

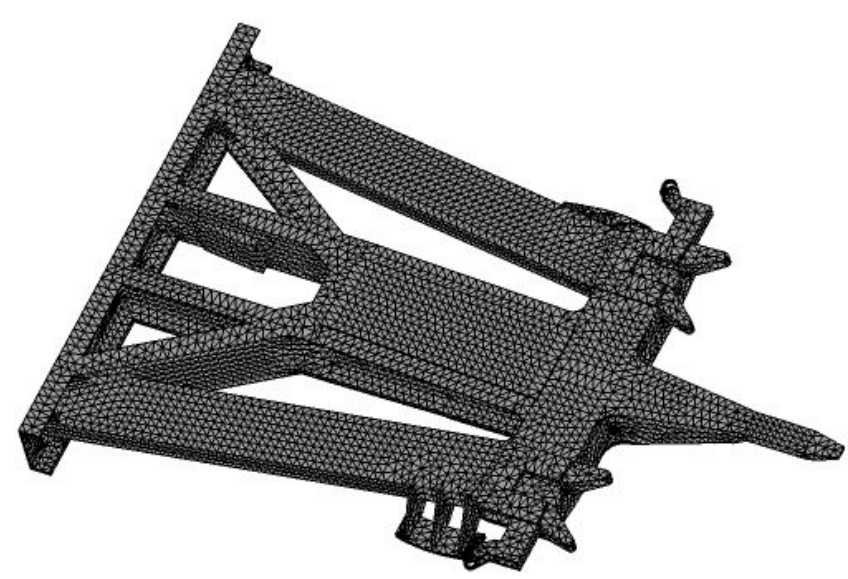

Rys. 10. Podział modelu obliczeniowego adaptera końcowego na elementy skończone

a)

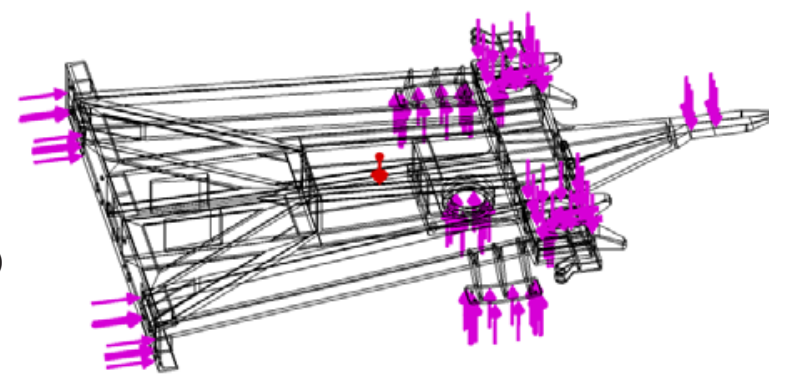

b)

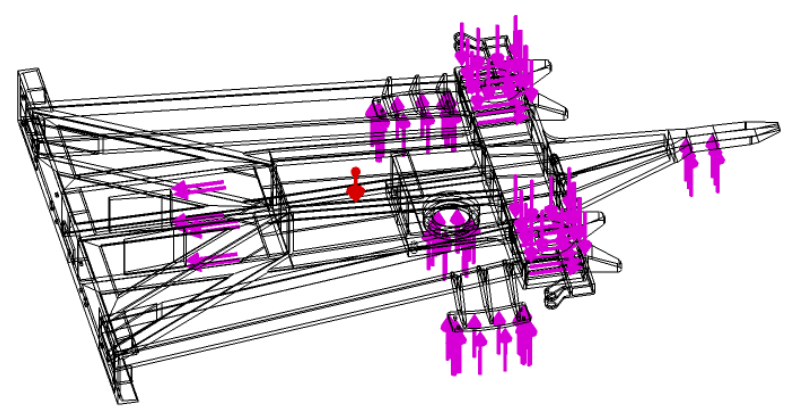

Rys. 11. Sposób przyłożenia sił do modelu: a) obciążenie wzdłużne ściskające b) obciążenie wzdłużne rozciągające
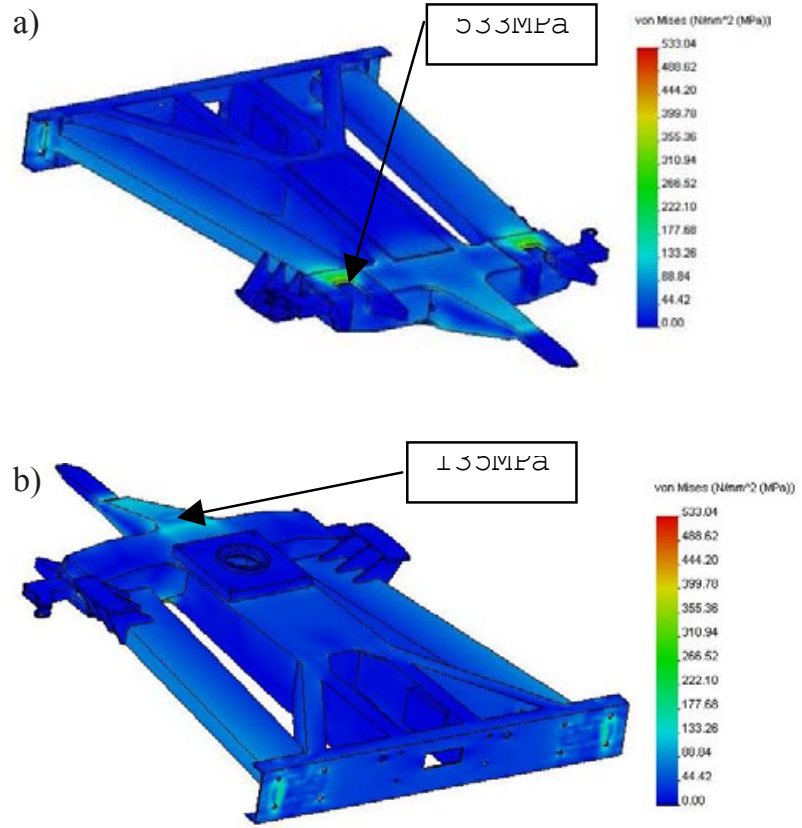

Rys. 12. Rozkład naprężeń zredukowanych w adapterze końcowym powstający przy ściskaniu siłą $1200 \mathrm{kN}$ : a) widok z góry, b) widok $\mathrm{z}$ dołu

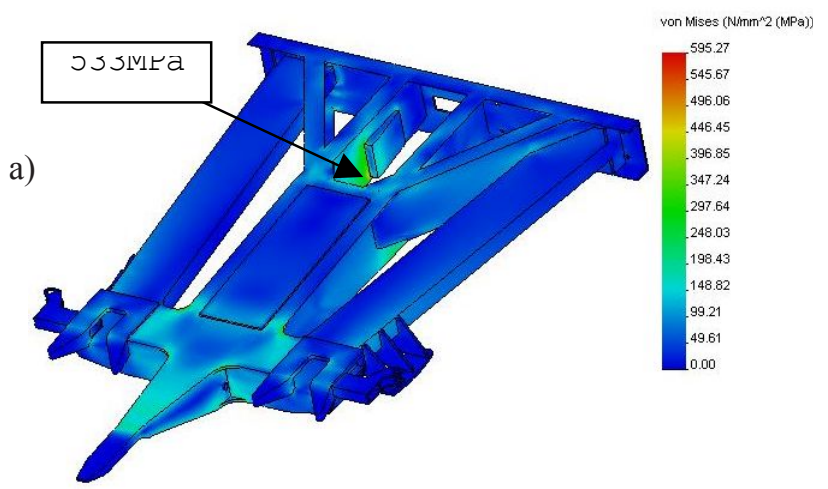

b)

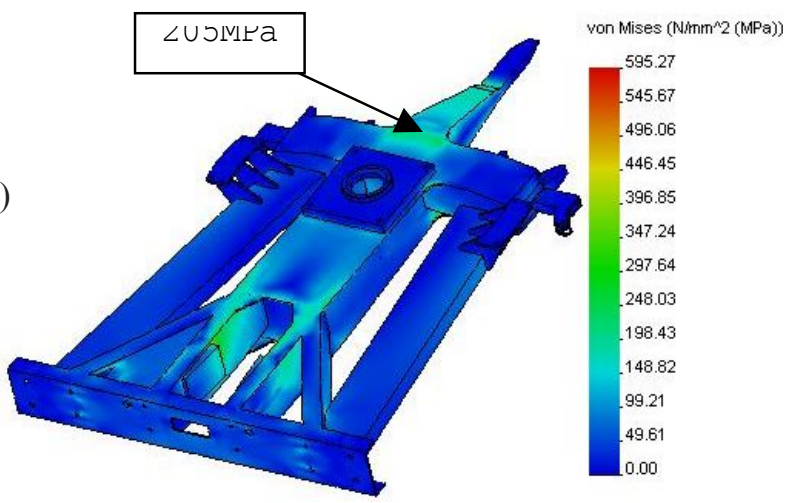

Rys. 13. Rozkład naprężeń zredukowanych w adapterze końcowym przy rozciaganiu siłą $1700 \mathrm{kN}$

a) widok $\mathrm{z}$ góry, b) widok $\mathrm{z}$ dołu

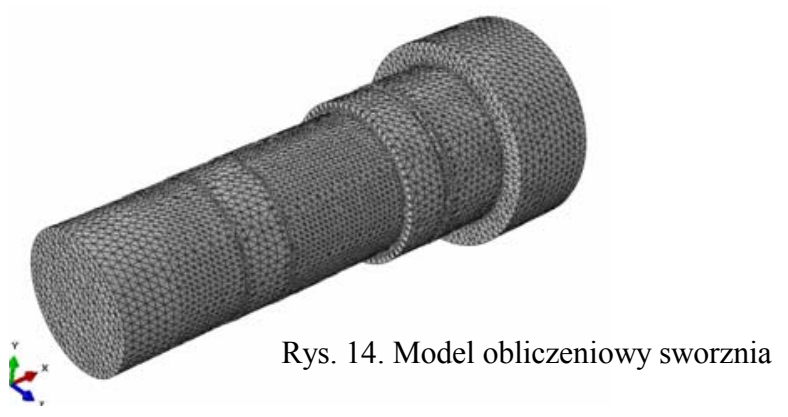

POJAZDY SZYNOWE NR 3/2012 


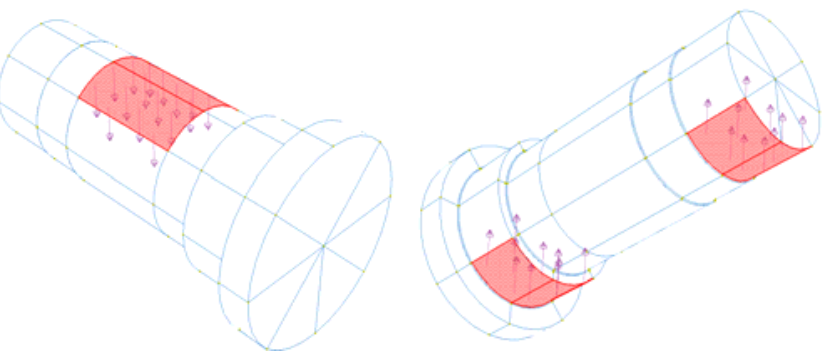

Rys. 15. Przykładowy schemat obciążenia wzdłużnego sworznia

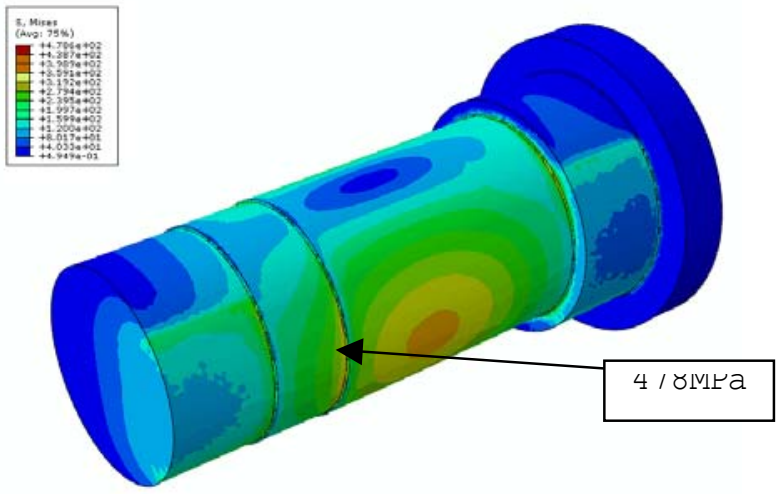

Rys. 16. Rozkład naprężeń zredukowanych konstrukcji sworznia od ściskania w osi zderzaków siłą 1200 kN i jednoczesnego działania obciążenia pionowego

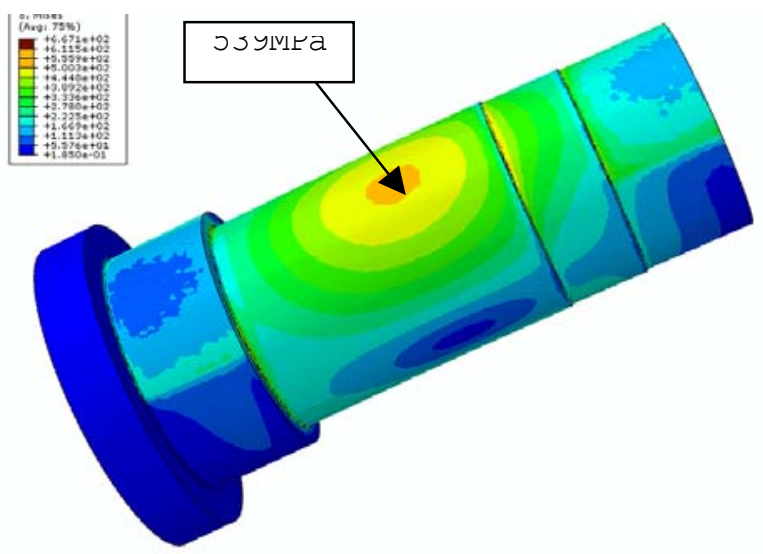

Rys. 17. Rozkład naprężeń zredukowanych w [MPa] konstrukcji sworznia od rozciaggania siłą 1700 kN w osi sprzęgu

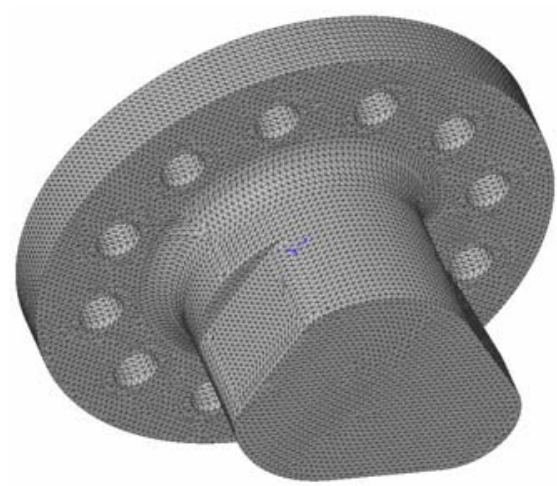

Rys. 18. Model obliczeniowy czopa a)

b)

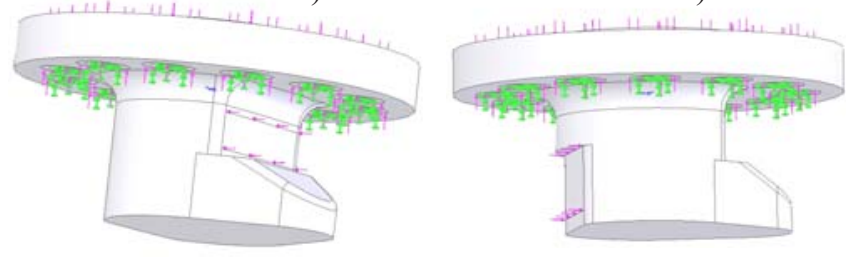

Rys. 19. Schemat obciążeń czopa: a) ściskanie, b) rozciąganie
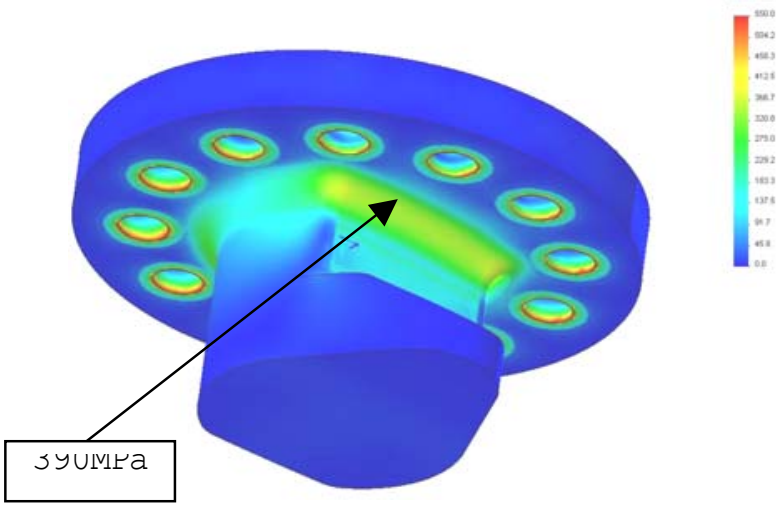

Rys. 20. Rozkład naprężeń zredukowanych w czopie powstający przy ściskaniu siłą $1200 \mathrm{kN}$

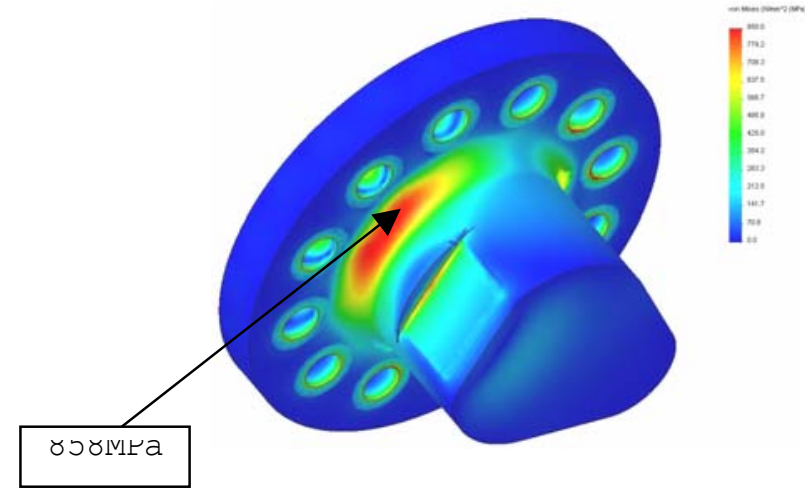

Rys. 21. Rozkład naprężeń zredukowanych w czopie powstający przy rozciąganiu siłą $1700 \mathrm{kN}$

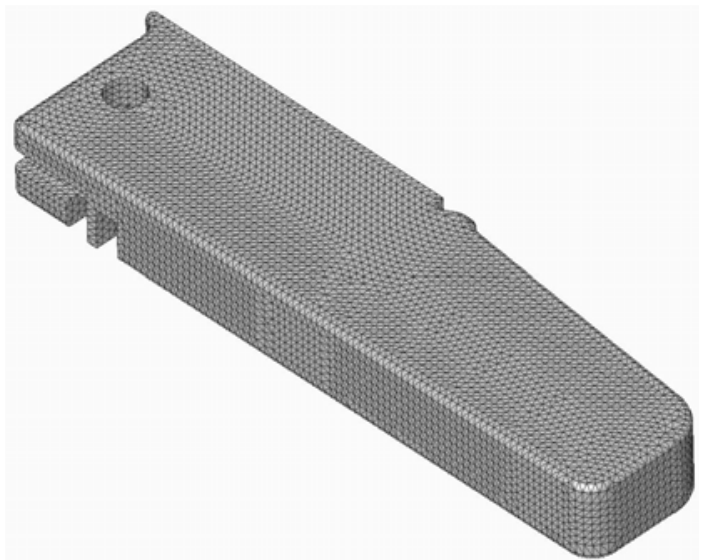

Rys. 22. Model obliczeniowy klina 

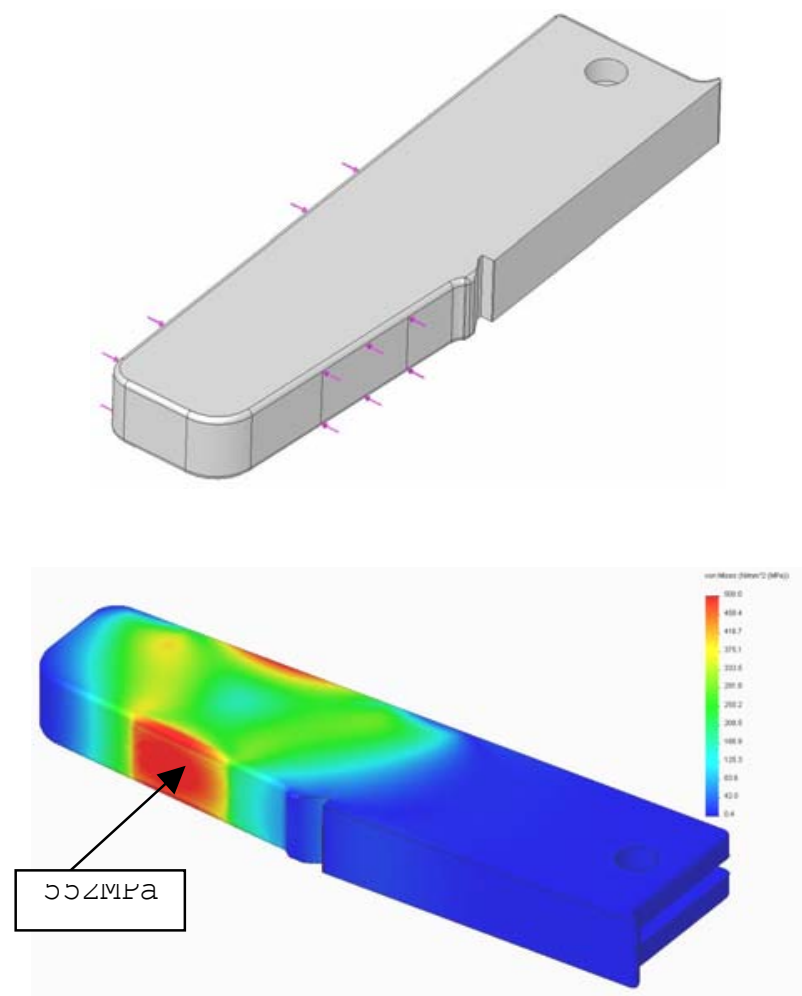

Rys. 24. Rozkład naprężeń zredukowanych w klinie ryglującym powstających przy rozciaganiu siłą $1700 \mathrm{kN}$ w osi sprzęgu

Wyniki przeprowadzonych badań symulacyjnych wytrzymałości konstrukcyjnej adapterów wykazały, że wymagane kryteria oceny zostały spełnione zarówno dla obciążeń eksploatacyjnych pociagu jak również dla próbnych obciążeń nadzwyczajnych.

Zarejestrowane maksymalne naprężenia dla obciążeń eksploatacyjnych nie przekraczają granicznej wartości Re a dla obciążeń nadzwyczajnych wartości $\mathrm{Rm}$.

\section{Literatura}

[1] Medwid M., Stawecki W., Czerwiński J., Cichy R.: System transportu bimodalnego przystosowany do ruchu , ,S" $i$, SS". Pojazdy szynowe 4/2011.

[2] UIC 597 System transportu kombinowanego szynowo drogowego. Naczepy wózkowe. Charakterystyki. Wydanie 1, styczeń 1991.

[3] UIC 577 Wagony towarowe. Obciazienia. Wydanie 5, grudzień 2005.

[4] OR 9322 Sprawozdanie z obliczeń wytrzymatościowych elementów połaczeniowych $w$ pociagu bimodalnym. Prace niepublikowane Instytutu Pojazdów Szynowych „TABOR”, listopad 2007.

[5] OR 9323 Sprawozdanie z obliczeń wytrzymatościowych adaptera dolnego zestawu bimodalnego-BMDc. Prace niepublikowane Instytutu Pojazdów Szynowych „TABOR", listopad 2007.

[6] OR 9324 Sprawozdanie z obliczeń wytrzymatościowych adaptera górnego zestawu bimodalnego-BMDc. Prace niepublikowane Instytutu Pojazdów Szynowych „TABOR", listopad 2007.

[7] OR 9325 Sprawozdanie z obliczeń wytrzymatościowych adaptera końcowego zestawu bimodalnego - BMDc. Prace niepublikowane Instytutu Pojazdów Szynowych „TABOR”, listopad 2007. 